\title{
DEVELOPING A FRICTION-STIR WELDING WINDOW FOR JOINING THE DISSIMILAR ALUMINUM ALLOYS AA6351 AND AA5083
}

\author{
ISKANJE VARILNEGA OKNA ZA TORNO VRTILNO VARJENJE \\ PRI SPAJANJU RAZLIČNIH ALUMINIJEVIH ZLITIN AA6351 IN \\ AA5083
}

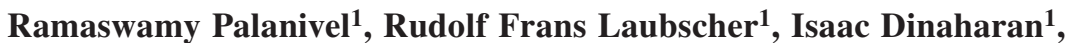 \\ Nadarajan Murugan² \\ ${ }^{1}$ University of Johannesburg, Department of Mechanical Engineering Science, Johannesburg 2006, South Africa \\ ${ }^{2}$ Coimbatore Institute of Technology, Department of Mechanical Engineering, Coimbatore 641014, Tamil Nadu, India \\ rpelmech@yahoo.co.in \\ Prejem rokopisa - received: 2015-03-04; sprejem za objavo - accepted for publication: 2015-12-21
}

doi:10.17222/mit.2015.049

\begin{abstract}
In this study a welding window was constructed for the relatively new welding process of friction-stir welding (FSW) to join the 6-mm-thick dissimilar aluminium alloys AA5083-H111 and AA6351-T6. The dissimilar joints were fabricated using different combinations of tool rotational speeds and welding speeds. The effect of the process parameters on the macrostructure of the joints was analysed and reported. Established along with the macrostructural analysis, a welding window was made. These windows will act as reference maps for selecting the appropriate FSW process parameters to produce defect-free welds of dissimilar aluminium alloys.

Keywords: friction stir welding, dissimilar joints, welding window, macrostructure
\end{abstract}

V študiji je bilo postavljeno varilno okno, za relativno nov postopek torno vrtilnega varjenja (FSW), za spajanje različnih aluminijevih zlitin AA5083-H111 in AA6351-T6 debeline $6 \mathrm{~mm}$. Zvari so bili izdelani s pomočjo različne kombinacije rotacijskih hitrosti orodja in hitrosti varjenja. Analiziran je bil vpliv procesnega parametra na mikrostrukturo zvarov. Na podlagi analize makro strukture je bilo postavljeno okno za varjenje. Ta okna služijo kot referenčna pri izbiri ustreznih parametrov torno rotacijskega varjenja različnih aluminijevih zlitin, za izdelavo zvarov brez napak.

Ključne besede: torno vrtilno varjenje, spoji različnih materialov, varilno okno, makrostruktura

\section{INTRODUCTION}

Environment friendly friction stir welding (FSW) is a solid-state welding process invented by the The Welding Institute (TWI) in 1991 in the UK to join metals, more specifically aluminum alloys, which are used in transportation industries, having a low melting point and difficult to join with conventional techniques. FSW uses a rotating tool with a pin travelling along the weld path and plastically deforming the surrounding material to make the weld. The warmth created by the rubbing between the rotating tool and the plates encourages a local increase in the temperature and softens the materials underneath the tool shoulder and simultaneously the plunged rotating tool pin moves and mixes the softened materials by intense plastic deformation, joining both in a solid-state weld. Attractive benefits of the FSW of aluminum alloys compared to fusion-welding processes are less distortion, lower residual stresses, fewer weld defects, no hot cracking and execution without a shielding gas. ${ }^{1-3}$ The fine microstructure in friction-stir welds produces good mechanical and metallurgical properties. By developing such technology, one of the most important facts is the possibility of joining different alumi- num alloys. ${ }^{4}$ The joining of dissimilar aluminum alloys offers the potential to give the advantages of different materials, often providing unique solutions to engineering-industry requirements.

The foremost FSW process parameters that determine the joint strength and microstructure are the tool rotational speed, welding speed, axial force and tool pin profile. ${ }^{2}$ The effects of the tool rotational speed and welding speed were investigated by various researchers $^{5-8}$ in order to obtain better mechanical and metallurgical properties of the welded joints. S. A. Khodir et al. ${ }^{9}$ studied the FSW of $2024 \mathrm{Al}$ alloy plate to $7075 \mathrm{Al}$ alloy plate and observed that the rise in welding speed tended to the formation of a kissing bond and pores. A. Steuwer et al. ${ }^{10}$ quantified the effect of the tool rotational speed and traverse speed on the residual stress of 3-mm-thick AA5083 and AA6082 joints. They reasoned that the tool rotational speed was a useful process variable to optimize the residual stress. The welding speed determines the exposure time of this frictional heat per unit length of weld and subsequently affects the grain growth. ${ }^{11} \mathrm{M}$. J. Peel et al. ${ }^{12}$ noticed a $35 \%$ drop in microhardness in the HAZ of the AA5083 side of the 
R. PALANIVEL et al.: DEVELOPING A FRICTION-STIR WELDING WINDOW FOR JOINING ...

dissimilar joint consisting of the aluminum alloys AA5083 and AA6062. N. Shanmugasundaram and N. Murugan ${ }^{13}$ developed a mathematical model to study the effect of FSW parameters on the tensile strength and elongation of dissimilar AA2024-AA5083 joints. S. Rajakumar et al. ${ }^{14}$ optimized the developed models using the software expert to maximize the tensile strength of the joints.

Despite the great quantity of published literature about the FSW, insufficient information exists in the selection of working ranges of the process parameters based on macrostructural observations. Hence in this investigation an attempt has been made in developing a welding window based on the macrostructural observation to produce defect-free welds.

\section{EXPERIMENTAL PART}

Rolled aluminum-alloy AA6351 and AA 5083 plates of size $100 \mathrm{~mm} \times 50 \mathrm{~mm} \times 6 \mathrm{~mm}$ were used in this study. AA5083 and AA6351 were kept along the retreating side and advancing side of the joint line, respectively. Due to better tensile properties ${ }^{15}$ the straight square tool pin having a shoulder diameter of $18 \mathrm{~mm}$, a pin diameter of $6 \mathrm{~mm}$ and a pin length of $5.6 \mathrm{~mm}$ was used to fabricate the joints. The manufactured FSW tool is shown in Figure 1. The FSW line was parallel to the rolling direction of AA5083-H111 and perpendicular to the rolling direction of AA6351-T6. The dissimilar butt welding was carried out on an in-house built FSW machine (M/s RV Machine Tools, Coimbatore, INDIA) by combinations of rotational speed $\left(800 \mathrm{~min}^{-1}\right.$ to $1200 \mathrm{~min}^{-1}$ ) and welding speed $(45 \mathrm{~mm} / \mathrm{min}$ to $85 \mathrm{~mm} / \mathrm{min})$. Axial force $(15 \mathrm{kN})$ and tool tilt angle (01) were maintained constant for all the joints. The single-pass welding procedure was followed to weld the joints. The specimens were made as per standard metallography procedures and etched with concentric Keller reagent. The digital image of the ma-

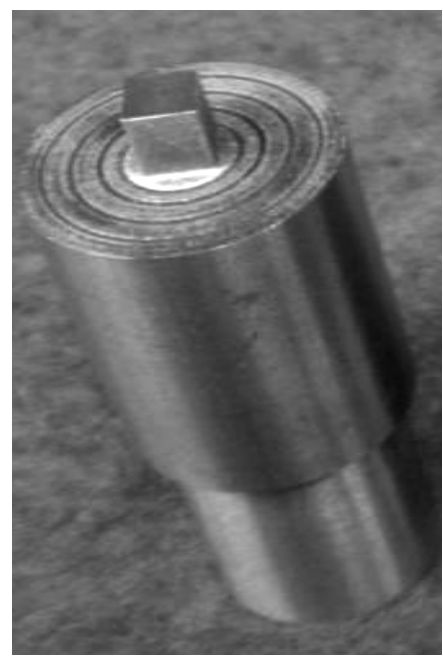

Figure 1: Photograph of manufactured FSW tool Slika 1: Posnetek izdelanega orodja za FSW

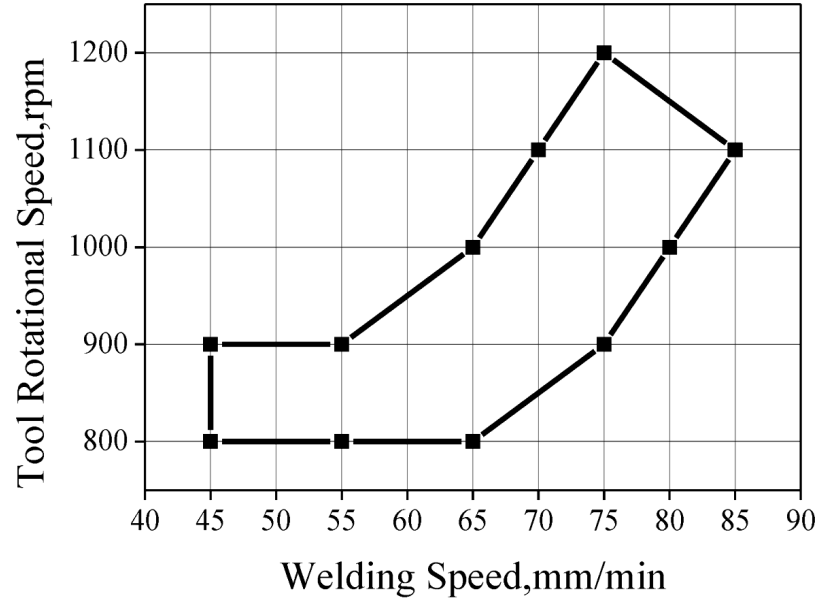

Figure 2: Welding window for dissimilar aluminium alloys Slika 2: Varilno okno za različne aluminijeve zlitine

crostructure of the etched specimens was captured utilizing a digital optical scanner to read the quality of the dissimilar joints produced by the various combinations of FSW process parameters. The welding window was made based on a macrostructural analysis for the joining of dissimilar aluminum alloy by different combinations of rotational speed and welding speed. Stoppage of material flow due to defects was observed using a scanning electron microscope. A verification test was made within the welding window region to validate the results.

\section{RESULTS}

Effects of the process parameters on the macrostructure of dissimilar joints are presented in Table 1, with the probable reason. Figure 2 shows the welding window of joining dissimilar aluminium alloys based on a macrostructural analysis. The tool rotational speed and
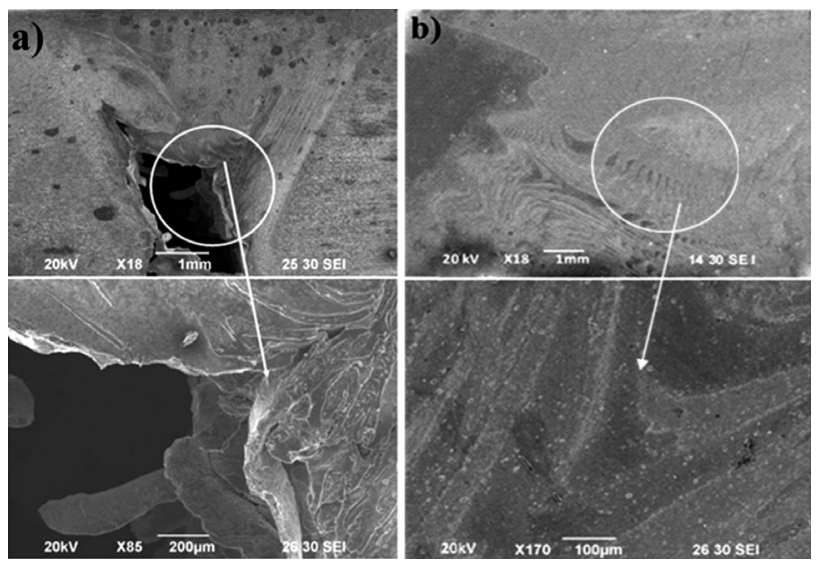

Figure 3: SEM images: a) defects of the joints and material flow clogged due to the defects, b) macrostructure without defects and proper material flow

Slika 3: SEM-posnetki: a) napake v spoju in preprečen tok materiala zaradi napak, b) makrostruktura brez napak in ustrezen tok materiala 
R. PALANIVEL et al.: DEVELOPING A FRICTION-STIR WELDING WINDOW FOR JOINING ...

Table 1: Effect of process parameter on the macrostructure of dissimilar joints

Tabela 1: Vpliv procesnega parametra na makrostrukturo spojev različnih materialov

\begin{tabular}{|c|c|c|c|c|}
\hline S.no & Parameter & Macrostructure & Name of the defects & Probable reason \\
\hline \multicolumn{5}{|c|}{ Welding speed of $45 \mathrm{~mm} / \mathrm{min}$} \\
\hline & Rotational speed, $\min ^{-1}$ & RS AS & & \\
\hline 1 & 700 & & $\begin{array}{l}\text { Pinhole at advancing side of } \\
\text { the weld zone }\end{array}$ & Insufficient stirring action of tool \\
\hline 2 & 800 & & No defects & $\begin{array}{l}\text { Sufficient heat generation and } \\
\text { interaction of tool }\end{array}$ \\
\hline 3 & 900 & & No defects & $\begin{array}{l}\text { Sufficient heat generation and } \\
\text { stirring action of the tool }\end{array}$ \\
\hline 4 & 1000 & & $\begin{array}{l}\text { Tunnel at the bottom, of } \\
\text { weld zone }\end{array}$ & High heat generation \\
\hline \multicolumn{5}{|c|}{ Welding speed of $55 \mathrm{~mm} / \mathrm{min}$} \\
\hline 5 & 700 & & Pinhole at retreating side & Insufficient stirring action of tool \\
\hline 6 & 800 & & No defects & $\begin{array}{l}\text { Sufficient heat generation and } \\
\text { interaction of tool }\end{array}$ \\
\hline 7 & 900 & & No defects & $\begin{array}{l}\text { Sufficient heat generation and } \\
\text { interaction of tool }\end{array}$ \\
\hline 8 & 1000 & & $\begin{array}{l}\text { Pinhole } \\
\text { At advancing side }\end{array}$ & High heat generation \\
\hline \multicolumn{5}{|c|}{ Welding speed of $65 \mathrm{~mm} / \mathrm{min}$} \\
\hline 9 & 700 & & $\begin{array}{l}\text { Tunnel defects at weld zone } \\
\text { collapse }\end{array}$ & $\begin{array}{l}\text { Insufficient heat and stirring } \\
\text { action of the tool }\end{array}$ \\
\hline 10 & 800 & & No defects & $\begin{array}{l}\text { Sufficient pulsating stirring action } \\
\text { and flow of plasticized material }\end{array}$ \\
\hline 11 & 900 & & No defects & $\begin{array}{l}\text { Sufficient pulsating stirring action } \\
\text { and flow of plasticized material }\end{array}$ \\
\hline 12 & 1000 & & No defects & $\begin{array}{l}\text { Sufficient pulsating stirring action } \\
\text { and flow of plasticized material }\end{array}$ \\
\hline 13 & 1100 & & $\begin{array}{l}\text { Tunnel defects at the } \\
\text { bottom of weld zone }\end{array}$ & High heat generation \\
\hline \multicolumn{5}{|c|}{ Welding speed of $75 \mathrm{~mm} / \mathrm{min}$} \\
\hline 14 & 800 & & $\begin{array}{l}\text { Tunnel defects at retreating } \\
\text { side of the weld zone }\end{array}$ & Insufficient stirring action of tool \\
\hline 15 & 900 & & No defects & Sufficient heat generation \\
\hline 16 & 1000 & & No defects & Sufficient heat generation \\
\hline 17 & 1100 & & No defects & Sufficient heat generation \\
\hline 18 & 1200 & & No defects & Sufficient heat generation \\
\hline 19 & 1300 & & $\begin{array}{l}\text { Tunnel defects at the } \\
\text { bottom of the weld zone }\end{array}$ & High heat generation \\
\hline
\end{tabular}


R. PALANIVEL et al.: DEVELOPING A FRICTION-STIR WELDING WINDOW FOR JOINING ...

\begin{tabular}{|c|c|c|c|c|c|}
\hline \multicolumn{2}{|c|}{ Welding speed of $85 \mathrm{~mm} / \mathrm{min}$} \\
\hline 20 & 1000 & & & Pinhole at advancing side & Insufficient heat generation \\
\hline 21 & 1100 & & No defects & Sufficient heat generation \\
\hline 22 & 1200 & & Tunnel defects at nugget & Insufficient stirring action of tool \\
\hline
\end{tabular}

the welding speed that are considered, which contribute remarkably to the generation of frictional heat during the welding. During welding the combination of process parameters that are having too high or too low heat input produces defects due to improper material flow. The rotational speed of $800 \mathrm{~min}^{-1}$ to $1200 \mathrm{~min}^{-1}$ yielded defect-free joints depending on the welding speed used and the welding speed in the range of $45 \mathrm{~mm} / \mathrm{min}$ to 85 $\mathrm{mm} / \mathrm{min}$ yielded defect-free joints depending on the rotational speed used.

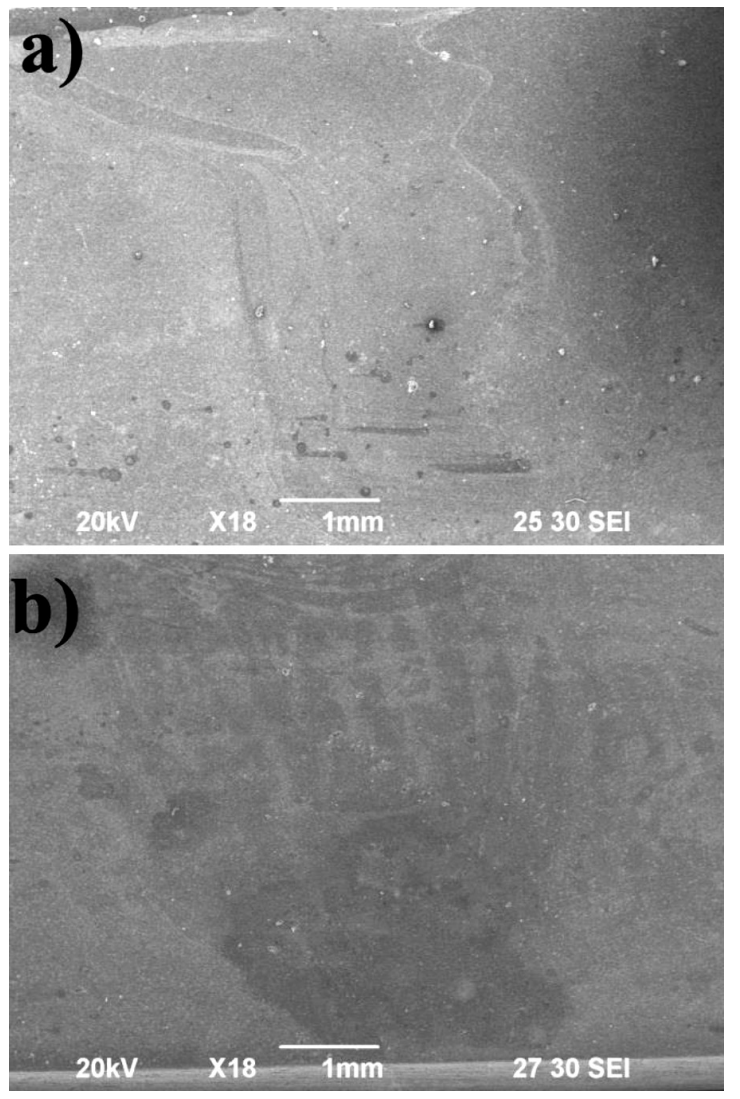

Figure 4: SEM image of the macro images of the dissimilar FSW joints with in the welding window region: a) $70 \mathrm{~mm} / \mathrm{min}$ and $900 \mathrm{~min}^{-1}$, b) $80 \mathrm{~mm} / \mathrm{min}$ and $1100 \mathrm{~min}^{-1}$

Slika 4: SEM-posnetek makro izgleda FSW-spoja različnih materialov, na področju varilnega okna: a) $70 \mathrm{~mm} / \mathrm{min}$ in $900 \mathrm{~min}^{-1}$, b) $80 \mathrm{~mm} / \mathrm{min}$ in $1100 \mathrm{~min}^{-1}$

\section{DISCUSSION}

Joining of aluminium alloys by fusion welding produces defects like hot cracking, porosity, slag inclusion, etc. with the mechanical and metallurgical properties. Usually, the friction stir welded joints are free from these defects since the absence of melting during welding; metals are joined in the solid state due to the heat generated by the friction and flow of metal by the stirring action. However, FSW joints are likely to have other defects like pinhole, tunnel defect, piping defect, kissing bond, cracks, etc. due to the improper flow of metal and insufficient consolidation of the metal in the weld zone.

A low welding speed and a high tool rotational speed increases the frictional heat due to the increased residing time of tool. Tool rotational speed results in stirring and mixing of the material about the rotating pin, which in turn increases the temperature of the metal. It seems to be the most important process variable since it is given to influence the weld speed. A low rotational speed to produce a low heat input. This low heat input results in lack of stirring and yields defects. It is clear that in FSW, as the rotational speed increases the heat input also increases. Figure 3 shows SEM images of the macrograph and mixing of the material of the joints. The material flow of the FSW joint from advancing side to retreating side and vertical movement (bottom to top) is collaged due to the defects formation as shown in Figure 3a. Proper mixing of the material due to the absence of defects is shown in Figure 3b. More heat input destroys the regular flow behaviour of plasticized material and a higher rotational speed causes the excessive release of stirred materials to the upper surface, which leaves voids in the weld zone. ${ }^{16,17}$ The lowest and highest welding speed produces defects due to the increased frictional heat and insufficient frictional heat generated, respectively. ${ }^{18}$ In general FSW at higher welding speeds results in a short exposure time in the weld area with insufficient heat and poor plastic flow of the metal and causes some voids, like defects, in the joints. Higher welding speeds are associated with low heat inputs, which result in faster cooling rates of the welded joint and hence yields defects. The developed welding window was validated with verification tests and the results are presented in Figure 4, having no defects within the welding-window regions. 


\section{MATERIALI IN TEHNOLOGIJE/MATERIALS AND TECHNOLOGY (1967-2017) - 50 LET/50 YEARS}

R. PALANIVEL et al.: DEVELOPING A FRICTION-STIR WELDING WINDOW FOR JOINING ...

\section{CONCLUSION}

Defect-free dissimilar FSW joints were produced under a wide range of rotational speeds and welding speeds. The friction stir welding window was developed to obtain defect-free welds.

The developed welding window will be applied as a ready reference to select the appropriate rotational and welding speeds to manufacture the defect-free joints.

\section{REFERENCES}

${ }^{1}$ R. S. Mishraa, Z. Y. Ma, Frictions stir welding and processing, Materials Science and Engineering R, 50 (2005) 1-2, 1-78, doi:10.1016/j.mser.2005.07.001

${ }^{2}$ R. Nandan, T. DebRoy, H. K. D. H Bhadeshia, Recent advances in friction-stir welding process, weldment structure and properties, Progress in Material Science, 53 (2008) 6, 980-1023, doi:10.1016/ j.pmatsci.2008.05.001

${ }^{3}$ Y. Uematsu, K. Tokaji, H. Shibata, Y. Tozaki, T. Ohmune, Fatigue behavior of friction stir welds without neither welding flash nor flaw in several aluminium alloys, International Journal of Fatigue, 31 (2009) 10, 1443-1453, doi:10.1016/j.ijfatigue.2009.06.015

${ }^{4}$ T. Saeid, A. Abdollah-Zadeh, B. Sazgari, Weldability and mechanical properties of dissimilar aluminum-copper lap joints made by friction stir welding, Journal of Alloys and Compounds, 490 (2010) 1-2, 652-655, doi:10.1016/j.jallcom.2009.10.127

${ }^{5}$ M. Ericsson, R. Sandstrom, Influence of welding speed on the fatigue of friction stir welds and comparison with MIG and TIG, International Journal of Fatigue, 25 (2003)12, 1379-1387, doi:10.1016/S0142-1123(03)00059-8

${ }^{6}$ P. Cavaliere, G. Campanile, F. W. Panella, A. Squillace, Effect of welding parameters on mechanical and microstructural properties of AA6056 joints produced by friction stir welding, Journal of Material Processing Technology, 180 (2006) 1-3, 263-270, doi:10.1016/ j.jmatprotec.2006.06.015

C. Leitao, R. M. Leal, D. M. Rodrigues, A. Loureiro, P. Vilaca, Mechanical behaviour of similar and dissimilar AA5182-H111 and AA6016-T4 thin friction stir welds, Materials and Design, 30 (2009) 1, 101-108, doi:10.1016/j.matdes.2008.04.045

${ }^{8}$ H. J. Aval, S. Serajzadeh, A. H. Kokabi, Evolution of microstructures and mechanical properties in similar and dissimilar friction stir welding of AA5086 and AA6061, Materials Science and Engineering A, 528 (2011) 28, 8071-8083, doi:10.1016/j.msea.2011.07.056

${ }^{91}$ S. A. Khodir, T. Shibayanagi, Friction stir welding of dissimilar AA2024 and AA7075 aluminum alloys, Materials Science and Engineering B, 148 (2008) 1-3, 82-87, doi:10.1016/j.mseb.2007.09.024

${ }^{10}$ A. Stewart, M. J. Peel, P. J. Withers, Dissimilar friction stir welds in AA5083-AA6082: The effect of process parameters on residual stress, Materials Science and Engineering A, 441 (2006) 1-2, 187-196, doi:10.1016/j.msea.2006.08.012

${ }^{11}$ T. Sakthivel, G. S. Sengar, J. Mukhopadhyay, Effect of welding speed on microstructure and mechanical properties of friction stir welded aluminum, International Journal of Advanced Manufacturing Technology, 43 (2009) 5-6, 468-473, doi:10.1007/s00170-0081727-7

${ }^{12}$ M. J. Peel, A. Stewart, P. J. Withers, Dissimilar friction stirs welds in AA5083-AA6082 Part II: Process parameter effects on microstructure, Metallurgical and Materials Transactions A, 37 (2006) 7, 2195-2206, doi:10.1007/BF02586139

${ }^{13}$ N. Shanmugasundaram, N. Murugan, Tensile behavior of dissimilar friction stir welded joints of aluminum alloys, Materials and Design, 31 (2010) 9, 4184-4193, doi:10.1016/j.matdes.2010.04.035

${ }^{14}$ S. Rajakumar, C. Muralidharan, V. Balasubramanian, Predicting tensile strength, hardness and corrosion rate of friction stir welded AA6061-T6 aluminium alloy joints, Materials and Design, 32 (2011) 5, 2878-2890, doi:10.1016/j.matdes.2010.12.025

${ }^{15}$ R. Palanivel, P. Koshy Mathews, The tensile behavior of friction-stir welded dissimilar aluminium alloys, Mater. Tehnol., 45 (2011) 6, 623-626

${ }^{16} \mathrm{~K}$. Elangovan, V. Balasubramanian, Influences of tool pin profile and welding speed of the formation of friction stir processing zone in AA2219 aluminium alloy, Journal of Materials Processing Technology, 200 (2008) 1-3, 163-175, doi:10.1016/j.jmatprotec. 2007.09.019

${ }^{17} \mathrm{~K}$. Elangovan, V. Balasubramanian, Influences of pin profile and rotational speed of the tool on the formation of friction stir processing zone in AA2219 aluminum alloy, Materials Science and Engineering A, 459 (2007) 1-2, 7-18, doi:10.1016/j.msea.2006. 12.124

${ }^{18}$ R. Palanivel, P. Koshy Mathews, I. Dinakaran, N. Murugan, Mechanical and metallurgical properties of dissimilar friction stir welded AA5083-H111 and AA6351-T6 aluminum alloys, Transaction of the Non Ferrous Metal Society China, 24 (2014) 1, 58-65, doi:10.1016/ S1003-6326(14)63028-4 